\title{
HISTORY
}

\section{THE ROLE OF AMERICAN AND SOVIET WOMEN REPORTERS IN COVERING WORLD WAR II: SPECIFICS OF COVERAGE OF MILITARY ISSUES IN 20th CENTURY JOURNALISM}

\author{
Tsitsino Bukia, Doctor of Social Sciences, Associate Professor, \\ Nana Parinos, Ph.D candidate in American Studies, Assistant Professor
}

Caucasus International University

Tbilisi, Georgia

DOI: https://doi.org/10.31435/rsglobal_ws/30112019/6792

\section{ARTICLE INFO}

Received: 29 September 2019

Accepted: 21 November 2019

Published: 30 November 2019

\section{KEYWORDS}

women,

combat correspondents,

WWII,

journalism.

\begin{abstract}
A war correspondent has no border, no gender, no religion or race. The only thing a war reporter has - the skills of delivering truth, reflection of the reality in the way it is.

The soviet space was absolutely closed to journalism and combat women journalists' involvement in wars. The field almost consisted of males. Consequently, it seems impossible to analyze and compare the technique of writing of American and Soviet

Women. If America freely accepts women for being actively involved in covering war activities, the Soviets obviously refused to do so.

The role of a war correspondent is much bigger than one can suppose. Being a war reporter is more than implementing their responsibilities. It goes deeper into the history. A professional combat reporter is a historian facing the history and keeping it for the next generation.

The paper considers advantages and disadvantages of being a female combat correspondent in the Soviet space and the United States of America.

The role of American and Soviet women reporters in covering WWII.
\end{abstract}

Citation: Tsitsino Bukia, Nana Parinos. (2019) The Role of American and Soviet Women Reporters in Covering World War II: Specifics of Coverage of Military Issues in 20th Century Journalism. World Science. 11(51), Vol.4. doi: 10.31435/rsglobal_ws/30112019/6792

Copyright: (C) 2019 Tsitsino Bukia, Nana Parinos. This is an open-access article distributed under the terms of the Creative Commons Attribution License (CC BY). The use, distribution or reproduction in other forums is permitted, provided the original author(s) or licensor are credited and that the original publication in this journal is cited, in accordance with accepted academic practice. No use, distribution or reproduction is permitted which does not comply with these terms.

Being a war correspondent is a very dangerous profession. It is a job where you are responsible for certain kind of things of great importance. When covering the information, a war correspondent must follow the rules to safe their own lives. The first stage goes to the reflection of unbiased situations, taking care of the information needed to be restricted for the mass in order to avoid victims. According to Roy Morris, the profession of a war correspondent, however, is a comparatively new development in human history. Scholars have long debated the identity of the first such correspondent. Candidates as varied and ancient as the Greek historian Thucydides, who wrote about the Peloponnesian War in 424 B.C., and Roman emperor Julius Caesar, who described his conquest of Gaul in 55 B.C, have been advanced although in both cases, the authors' chronicles were written several years after the wars themselves [5].

The situation is getting harder when it comes to gender. To the mass, a war correspondent is a male-oriented job, however, there has never been a lack of women combat correspondents. Talking about women war reporters, one subconsciously associates them with masculine world. 
Even being a woman journalist, Mary, S. Mander mentions a personal pronoun "he" instead of "he or she", or "they". "Every journalist dreams of the really big story. And for that encounter his arms himself with the tools of his trade: good interviewing skills, prescient nose, and clear writing". [3, p. 138] A war correspondent has no border, no gender, no religion or race. The only thing a war reporter has - the skills of delivering truth, reflection of the reality in the way it is.

The role of a war correspondent is much bigger than one can suppose. Being a war reporter is more than implementing their responsibilities. It goes deeper into the history. A professional combat reporter is a historian facing the history and keeping it for the next generation. To Mary S. Mander "journalists are often compared to historians, they seem to me to be more like secret agents. Their job during wartime is a dangerous one and it is done for their country. Sometimes it gives them access to the powerful, and they are tempted to become statesmen, to consult, to strategize, to offer advice. Military strategy is a very seductive mistress. [3, p. 139].

It should be noted that an American journalist Virginia Cowles in her own publication "the beginning of the end" (included the in the book Looking for trouble) describes Paris evacuation of June 1940. The paper was written in the format of reportage. Telling the story seems to have a fictional and emotional nature and it can be perceived as a prosaic story rather than a publication. In spite of that, Virginia Cowles as a war correspondent makes some critical notes about the Government of France being unable to evacuate people in an organized way. She outlines that leaders left the people and that's why France "doomed" and the moral was the case of faith. As to the publication itself, it gives a full and distinct picture about the attitude of the journalists of that time towards the government of France, evaluating the chances of government pessimistically [1, pp.25-34].

Susan B. Anthony published an article in May 1944 in the New Republic where she behind the frontline scene described the conditions of women workers. The journalist uses the format of an interview-monologue for describing a story of woman with five children. Also, she is sharing the problems and troubles of other women. The text contains a component of evaluation at the end of the publication where she states that in case of having better conditions the productivity of those women would have remained high or doubled at least. The text stands out for its fictional storytelling nature and basically is focused on highlighting the problem. [1, pp. 445-451]

A combat correspondent of Chicago Daily News, Helen Kirkpatrick published a paper on August 26, 1944 under the title Daily News Writer sees Man Slain at Her Side in the Hail of Lead which represents a reportage in the period of Paris' bloody days when the celebration of freedom from fascist militia converted into the massacre days. The correspondent is focusin the right target and making distinct accents on ongoing issues. Kirkpatrick stated that it was a planned attempt from German side aimed at killing as much authorities as they can possibly. This was a good start for creating panic among the people. Her comments were quite self-confident and there Is a trace of being an onlooker, making the huge effect of attendance [1, pp. 486-489].

We have to outline the biased publication of Virginia Irwin that was published in St. Louis PostDispatch in May 9, 1945, under the title A Giant Whirlpool of Destruction. The paper pretended to be a reportage reflecting the World War II. The author is describing the meeting and celebration of Americans and Russians in the limelight of Berlin. Irwin cannot help admiring about the hospitality of the Russians, with accents on Nikolai Kovaleski, Guard Mayor. To the journalist, this was Russian revenge for Leningrad, Stalingrad, Sevastopol and Moscow. We believe that Virginia Irwin is making absolutely biased comments and evaluation when she stated that Germans were afraid of Russians in the way no one ever feared the conquering side. The format of the paper is out of the accepted genre of reportage. Although, it is somehow gives the association of the aforementioned genre. But, mostly, the paper is enriched with personal experience, emotions and celebration of victory. Our analysis are based on her very statement at the end of the paper where she announced about her readiness for taking Berlin. The sense of objectivity is absolutely lost. These kind of comment are unaccepted for journalists, specifically a war reporter. [2]

Matha Gellhorn famous for being one of the greatest war correspondents of her time in one of her texts, under the title The Battle of Bulge of December 1944, described her thoughts on the way to Bastogne. The period given in the publications meets the counteroffensive of Germany through Luxemburg and Belgium. The storytelling is too fictional. The author named the human actions as inhuman ones and for giving her own mark, she created some fictional and emotional faces. The material has no journalistic value. On the background of passed Christmas, she painted bloody pictures of war. [Article is available at [2]]

Gellhorn's other publication published in Collier's under the title The Price of Fire mainly described the victim injured in the war. The case was about young man's big loss, losing his eyes. The storytelling in 
this specific case is too poetic. The given material seems impossible to be used as a publicist paper or named that way. In the same magazine she published her paper The First Hospital Ship and Dachan using the manner of expressing the facts within the framework fictional storytelling. Her stories consists of no analysis, critics, evaluations of ongoing situations or coverage of issues but sharing her own expressions and feelings. She is not in full compliance with the name of the position - a War Correspondent [2, 6].

Unlike Gellhorn's papers given above, Das Deutsche Volk which was published in Collier's of May 1945 distinguished with elements of analyses and the criticism of Nazism. The author outlines her personal opinion where literature style of hers was not put aside.

The publication of Hook and Redmond appeared in Life in June 1942 under the title Bataan Nurses described one specific case of the witnesses being nurses at the same time. The paper is enriched with Information on ongoing issues which contains no analytic components, justification, the way outs or evaluation of the current situation. The publication belongs to information genres in contrast to fictional ones mentioned above.

The book From Pearl Harbor to Tokyo contains the publication of Cecil Brown Prepare to Abandon Ship. The material of 1945 represents a reportage with fictional accents. The same author published a paper Keep Your Head Down of 1945 in Malay Jungle War. In contrast to the previous material, the text is enriched with analysis with a lack of fiction in it. That gives us an opportunity to conclude that this author in this specific paper used neither renowned tendency of fictional storytelling nor the worldwide technique of enriching the text with personal emotions and expressions.

The following cases given in the paper seems quite remarkable since all of them use one and the same style for writing. Damn a Torpedoes by Hellen Lawrenson at Harper's Magazine, July 1942. The text consists of few elements of evaluation. Over the Lines by Margaret Bourke White published in Purple Heart Valley of 1944. Girls from Elkton, Maryland by Marry Heaton Vorse published in Harper's Magazine in March 1943 where the author described a county and its inhabitant women.

The next less known author that deserves our attention is Dorothy Thomson who in Let the Record Speak of 1939 wrote a paper under the title "Peace" - The Beginning of Crisis. In this publicist article criticized the document of treaty (Four Power Record). The war correspondent named it as a "fantastic piece of paper" and believed that was not a defensive document. In her own words that meant the rule of terror and she perceived it as Germany's provoking actions towards all European War. The author distinctly expressed her personal standpoints and did not back out in any single word to criticize the politics. According to Dorothy "Peace" is not absence of war and the "Peace" of that time was based on lawlessness. She outlined that "the victory goes to Hitler". To Thomson, with the help of the above mentioned document Hitler scored. Thereafter, Thomson predicted the future crisis and consequences in Europe.

A combat correspondent Marguerite Higgins in New York Herald Tribune of April 3, 1945 published a paper Freed Captives Fill Roads That to Lead to France which concerned the issues of displaced persons. The expression genre goes hard news. The author used no literature element unlike her contemporaries.

A Russian-born Sonia Tomara received her education in Russia. During the World War II she was writing her publications for New York Herlad Tribune. She regarded as the first femal war correspondent of WWII. The Case of Tomara is a distinguished and important one. It should be noted that, she was named as a Soviet and American war reporter at the same time. Being born on the land of U.S.S.R she moved to the United States and worked for an American newspaper. Having Russian educational background, she looked at the frontline within the Soviet eyes. Analyzing her manner of the storytelling, it can be concluded that her writing style differs from the style of American journalism, namely combat correspondent. Her paper under the title Nazi-Red Animosity Described Along Tense Frontier Border in Poland published in New York Herald Tribune of November 20, 1939. The material can be named as a reportage. She wrote accurately in a style appropriate to purpose: the content is brief and clear as it typical of this sort of genres. Tomara covered the issue of the boundary between Poland and Hungary which was controlled by Russians and Germans.

The other material (French Conceal Despair Move as Automatons) by Sonia Tomara published in New York Herald Tribune of June 19, 1940 was written with the same manner typical of Tomara. The paper outlined Prime Minister Petain's decision towards stopping the war that automatically meant Hitler's victory. She described the gestures, facial expressions, movement and conversations among the audience attending the café. She described their despair and pain facing the position of giving up. The paper is distinguished with a critical style and contained confident assessment of the ongoing war. 
The job of the war correspondent is defined by the risks and dangers involved with getting the story: death, injury, kidnap, harassment and imprisonment, among others [4, p. 9].

Beside greatly, systematizing the censorship office, the U.S army press division also began consciously to appreciate the press as a propaganda tool during WWI. This awareness worked in such a way that by WWII, the press division identified itself as "Public Relations" which implies the use of propaganda $[3$, p. 51$]$.

The research of Soviet journalism during the WWII revealed that war coverage was a male- focused field. Not taking into consideration, a Russian born and educated woman Sonia Tomara who worked for New York Herald Tribune and consequently, cannot be named as a soviet journalist. The only journalist who actively covered WWII was Ukrainian born Natalia Bode. She was a photo journalist who took pictures of the frontline throughout 1941-1945. Her pictures were published not just in Soviet countries but abroad too.

Conclusions. Thereby, there search made shows that there was a big gap between American and Soviet journalism in covering war issues. There were some radical differences worth mentioning:

The soviet space was absolutely closed to journalism and combat women journalists' involvement in wars. The field was completely consisted of males. Consequently, it seems impossible to analyze and compare the technique of writing of American and Soviet women. If America freely accepts women for being actively involved in covering war activities, the Soviets obviously refused to do so.

When having, Higgins, Kirkpatrick, Antony, Gellhorn and so on in the United States, the Soviets can be proud of an only woman photojournalist since having no other ones neither in publications nor in illustrations.

Considering American journalism in the whole, it can be concluded that, the US. Did not divide journalism between male and females since the gender case in this specific field was not a topic of interest. American journalism broadly covered the WWII with all it aspects and details. America had quite a lot of women journalists doing their job in specific style and technique.

On the basis of the considered and analyzed materials, we can conclude that American war combat women on a regular basis wrote their articles in a literature style. Their texts are much more emotional than analytical. The content is enriched with metaphors and had a lack of information.

A reportage can be named as the dominant genre in American journalism and history of the American women combat correspondents writing style.

One of the women that can be presented as a pure analytical journalist is Dorothy Thomson. She offers her specific style for writing containing predictions that made her much different from the women who offered a belletristic style instead of journalistic one.

Comparing the same war period women journalists' style in the U.S and Soviet Union, we can underline the case of Tomara. Being a Russian born and educated and then immigrated to America, Sonia Tomara is the only woman war correspondent whose style of writing worth paying attention. Besides this, her style of writing radically differs from the style offered by U.S women journalist. Educated in Russia, Tomara was an example of professionalism where she strictly followed all the rules for genres' specific. We can conclude that being educated in Soviet Union, Tomara is an example of how soviet women war correspondents could have written in case of having possibility of covering WWII.

Thereafter, America and its female correspondents had a free space for writing, having no restrictions in covering while the soviets with its closed boundaries and limits had no women combat correspondents but on the basis of Sonia Tomara it appears that they had the sense of genre and skills for following the rules of journalism.

\section{REFERENCES}

1. Ambrose, S. H. (2001). Reporting world War II, American journalism 1938-1946. New York: Literary classics of the United States.

2. Gellhorn, M. (1988). The Face of war. New York: New York, NY:Atlantic Monthly Pr.

3. Mander, M. S. (2010). Pen and sword, American war correspondents 1898-1975. Illinois: The University of Illinois

4. Mclaughlin, G. (2016). The War correspondent. Pluto Press. Retrieved December 10, 2018, from https://www.jstor.org/stable/j.ctt19qgf0x.6

5. Morris Jr., R. (2018). The Pen \& the sword: A Brief history of war correspondents. Retrieved December 10, 2018, from https://warfarehistorynetwork.com/daily/military-history/the-pen-the-sword-a-brief-historyof-war-correspondents/

6. Samuel Hynes, A. M. (1995). Reporting World War II American journalism 1944-1946. New York: Literary Classics of the United States. 